\title{
In praise of lesser books
}

\author{
Classic textbooks bring renown to their authors, but students rarely \\ read them. Walter Gratzer argues that publishers would do well to \\ woo a new breed of textbook writer.
}

\begin{abstract}
DOROTHY Parker is supposed to have said in an address to the New York Horticultural Society: "You can lead a horticulture but you can't make her think". So it is with students. The universities, at least in Britain, are engines for the education of the self-educating: the politician whose entry under education in Who's Who reads "self-educated at Eton and King's" many not have been joking. Those without the gift become the silent majority of the lecture room, those rows of disembodied uvulas, victims of a conspiracy of disregard; for our academics adhere to the illusion that they are members of a community of scholars, entrusted with the propagation of their field of scholarship by way of research, and incidentally with the reproduction of their kind.
\end{abstract}

The first-year undergraduate, bereft of the intensive teaching he will have had in the sixth-form, is apt to feel the more aggrieved when he discovers that the sources recommended by his lecturers are not substitutes for the excellent range of tried and dependable textbooks that will have been his companions through the preceding years. More, he will be expected to learn primarily from the most anachronistic and discredited of all the instruments of instruction, the lecture. Dr Johnson hit the nail on the head as always. "People" he wrote "have now a days got a strange opinion that every thing should be taught by lectures. Now, I cannot see that lectures can do so much as good as reading the books from which the lectures are taken".

So what of these books? Most academic scientists cleave to certain classic texts, on which very often they were brought up. Everyone can identify a number of magisterial works, many of which, even in an active subject, may endure for 50 years and more. Nearly always, they are written by luminaries in their fields, and at best they may throw a new perspective on an entire discipline and invest it with new life and excitement. The intellectual impact of such legendary works is often enormous and their influence may pervade the working lives of generations of scientists. Not long ago a leading theoretical chemist said of one celebrated textbook that its influence had set chemistry back 20 years. It is no mean book that can attract such obloquy, even allowing for a dash of odium theologicum. The effects of some of these books on the professional personae of scientists can perhaps best be compared to those of Spock's baby books on the per- sonalities of Americans - first, second and third edition babies, brought up in accordance with the different precepts on toilet training enunciated in successive revisions.

A classic, according to Mark Twain, is something that everyone wants to have read but nobody wants to read. Most undergraduates, I suspect, derive little profit or pleasure from the classic textbooks, for these are not written with the typical student in mind. They are conceived, I imagine, with an eye to posterity and as a bid for a posthumous academic progeny and with it immortality for the culture-genes, in an age in which citations of publications in the primary literature fall off according to a first-order decay law, with a half-time of a year or so. Successful scientists are seldom plagued by excessive modesty, and anyone who doubts that the prospect of oblivion for their work holds the liveliest terrors might reassure himself by recalling Bertrand Russell's story about the recurring nightmare that visited him in middleage: he saw before him the Recording Angel moving along the library shelves, selecting those few books that would be spared from the fire on the Final Day. Each time he would observe with agitation that the angel had reached the letter $R$, and that his hand was hovering above Principia Mathematica; and then he would wake, trembling.

If I do not misjudge them, university teachers might well suggest that it is no fault of theirs if undergraduates are not available who are worthy of their textbooks. Bertolt Brecht's rejoinder to the complaint from the East German regime that the performance of the country's workers was unworthy of the Government's economic plan was to ask why the Government should not then dissolve the people and elect another. Academics are bred and selected for their prowess at research and nothing else, and, as I have suggested, neither they nor the system have much patience with the concerns of students, except the few that the system will claim for its own. If you do not believe me, here is a higher authority on the subject, Cardinal Newman, writing a century ago:

To discover and to teach are distinct functions; they are also distinct gifts, and are not commonly found united in the same person. $\mathrm{He}$, too, who spends his day dispensing his existing knowledge to all comers, is unlikely to have either leisure or energy to acquire new. Common sense of mankind has associated the search after truth with seclusion and quiet. The greatest thinkers have been men of absent minds and idiosyncratic habits, and have more or less shunned the lecture room and public school.

I would further suggest that the chief aim of the university lecture is more to establish the ascendency of the lecturer over the Great Unwashed before him than to dissipate his hard-won knowledge. Why otherwise has the lecture survived as an institution so many centuries after the Venerable Bede amazed his contemporaries with his ability to absorb the contents of a book without articulating is aloud? It was, I believe, another mediaeval divine who said: "The vanity of teaching often tempteth a man to forget that he is a blockhead".

One of the two authors of a highly successful series of American chemistry texts accounted for their popularity with students by his resolve, and that of his colleague, to concentrate their efforts on explaining the subject to even the dullest student, rather than to show off their own knowledge - something to which the very character and training of most academics predisposes them. Few people take kindly to being persuaded that they are not after all very bright, nor will they easily forgive the bringer of such tidings. Professional teachers are less likely to offend in this way than academic research workers, and students will reward them by buying their books.

There are now a number of admirable university textbooks, written by teachers, professional textbook writers or others who have never held a test-tube, even, in at least one case, a journalist. It may be that we are witnessing the emergence of a new craft. The products are not monuments of scholarship that illuminate the field anew; their object is more modest but no less estimable, and they probably find little favour among university lecturers, but if they work for the student in the modern education mill, he will vote with his wallet. There are of course striking exceptions to my rule, even books of quality written, against all the odds, by committees, as indeed the pages that follow will show; in any case the minority of students with an academic bent, as well as research students and the rest of us, have our special needs. I suspect, however, that most new books satisfy neither one group nor the other, and vanish instantly into that bourn from which no book returns as a second edition. If I were a publisher in quest of your fiveedition man, I rather think it is the new professionals that I should look to rather than the scientific magi; and I should keep in mind how one of the most successful of all writers summed up her approach to her craft, the romantic novelist, Ruby $\mathbf{M}$. Ayres, quoted in her obituary in The Times: "First I fix the price. Then I fix the title. Then I write the book"'.

Walter Gratzer is in the MRC Cell Biophysics Unit, King's College, University of London. 